\title{
Grazing management in temperate grassland of K umaun Himalaya for soil water conservation
}

\section{PremPrakash}

Department of Botany, Govt. P.G. College, Dwarahat, Almora (Uttarakhand), INDIA

E-mail: drpp_bot@yahoo.co.in

Received: M arch 25, 2013; Revised: April 29, 2013; Revised receied: August 10, 2013

\begin{abstract}
Overgrazing by livestock has caused major changes in the productivity and composition of rangeland vegetation in India. The main problem stems from the fact that the carrying capacity of rangelands is low as a result of low vegetation cover, and is decreasing with range degradation. This has an impact on land degradation which affects the rangeland hydrology. Thus the aim of this study was to determine the physio-hydrological responses of soil to different intensities of livestock grazing and land management by comparing the effect of uncontrolled grazed land and fenced off (ungrazed) land. There is a need to understand the hydrology of rangeland so as to propose ways of improving carrying capacity of rangeland. The study site had two different treatments: fenced off to prevent grazing, and uncontrolled grazed treatments. Plant biomass was measured at the end of the season. The results showed that there is a significant difference in infiltration rate and soil moisture among the two treatments. Infiltration rates were substantially greater in summer than in winter. On day 1 the steady infiltration rate in summer was twice the winter rate. The infiltration rate in summer on day 2, which is a better measure of the steady rate, was 2.5 times the winter rate. The differences between seasons were statistically very significant $(p<0.001)$. The effect of treatments on soil moisture was proportional to the effect of vegetation, as well as the effect of soil type on soil moisture, thus vegetation production depends on soil moisture.
\end{abstract}

Keywords: Biomass, Infiltration, Livestock, Rangeland, Soil hydrology

\section{INTRODUCTION}

Overgrazing of rangeland is not caused only by the number of animals grazing in a given area, but rather by poor management of grazing areas. Grazing management is a tool that can be used to increase the amount of soil moisture that becomes available for plant use. Therefore, it is necessary to manage grazing areas in order to conserve water for biomass production. Because of its importance for grazing and other grassland agricultural production, grassland productivity has been extensively investigated using various methods. Rainfall is the principle input of water into the rangeland system and thus plant biomass production is some function of the total rainfall. If rainwater has not taken the form of runoff, or has not evaporated, then it has infiltrated into the ground. To promote plant biomass, this is the pathway that should be favoured. When runoff occurs, it's erosive nature transports soil nutrients from the site and can even reduce A-horizon (topsoil) depth, decreasing the amount of water that can be stored in the soil profile. The A-horizon is rich in organic matter, giving it the ability to hold more water than deeper soil horizons. There are many aspects of good rangeland management, such as the use of an appropriate stocking rate, rotational grazing with rest periods, the controlled use of fire, and improving the herbage composition, but water management is also important (Platts and Nelson, 1989).

Land degradation due to population and livestock pressures is a major concern in the semi-arid tropics of southern Africa, leading to soil erosion and deforestation (Scoones, 1992; Milton et al., 2003). This in turn can lead to increased runoff and decreased infiltration to soil and groundwater (Lovell et al., 1994) and other negative effects on soil physical characteristics of rangeland such as decreased soil water holding capacity. Decreasing the velocity of overland flow also promotes increased infiltration (Stomph et al., 2002).

Infiltration is the movement of water into the immediate soil surface. It is an important component in watershed modeling for the prediction of surface runoff. For a given soil, the land use pattern play a vital role in determining the infiltration characteristic and is of particular interest to soil scientist, hydrologist, agronomist, geographers and agricultural engineers (Suresh, 2008).There are, however, feedbacks between vegetation and the water cycle that do not directly result from plant activity. One such feedback is the alteration of the infiltration capacity of soils through biotic processes. This positive feedback (i.e., the presence of vegetation increases infiltration capacity) is well documented in arid ecosystems where it can lead to spatial organization (Bromley et al., 1997; 
Couteron and Kokou, 1997; Rietkerk et al., 2002; Saco et al., 2007). The processes that generate vegetation infiltration capacity feedbacks have been widely explored in drylands (Bergkamp, 1998; Dunkerley, 2000a, 2000b, 2002; Wainwright et al., 2002). Keeping in mind these facts this study was conducted during the year 2009 to conserve water through grassland or grazing management in the temperate zone.

\section{MATERIALS AND METHODS}

Study area: The study was conducted near Suraiketh located in district Almora (Latitudes $30^{\circ} 22^{\prime}-30^{\circ} 14^{\prime}$ and Longitudes $\left.78^{\circ} 56^{\prime}-78^{\circ} 47^{\prime}\right), 20 \mathrm{~km}$ north of Dwarahat in Uttarakhand (India) extending from 1200-1500 m above mean sea level. The region comprises temperate zone of Himalaya with Pinus as dominant tree species with graminoides as predominant under canopy vegetation and therefore, used as grazing land by local inhabitants. The climate of the area is warm-temperate with moderate summers and severe winters with an annual precipitation of $250 \mathrm{~cm}$, most of which commences during the rainy season.At the study site, two plots were demarcated, the first plot was fenced off to exclude grazing, and the second plot was not managed and was thus a grazed control. The necessary climatic data were provided by the UPROBE (Participation of real time in education in Uttarakhand), Dwarahat, Almora.

Soil moisture data was collected to assure similarity between treatments so that differences in infiltration rates could be attributed to management changes. The soil moisture was measured at the depth of $0-10 \mathrm{~cm}, 10-15 \mathrm{~cm}$ and $15-20 \mathrm{~cm}$, since the majority roots of most rangeland plant species are within the top of 12 to $24 \mathrm{~cm}$ of the soil (Meterlkamp, 2001). Total net productivity (TNP) assessment is based on increase in plant biomass employing the short harvest method (Odum, 1960). The aboveground net production has been calculated by summing the positive monthly increments in the standing crop (Singh and Yadava, 1974).

Infiltration rates were determined under the two different treatments from January 2009 to December 2009. A tension infiltrometer of $150 \mathrm{~mm}$ area disc and $19 \mathrm{~mm}$ area column with $10 \mathrm{~mm}$ tension head was used to measure infiltration rates (Fig. 1). In this method, the infiltrometer was filled with water to a determined water level and placed on the ground, level and undisturbed by wind. The time at which

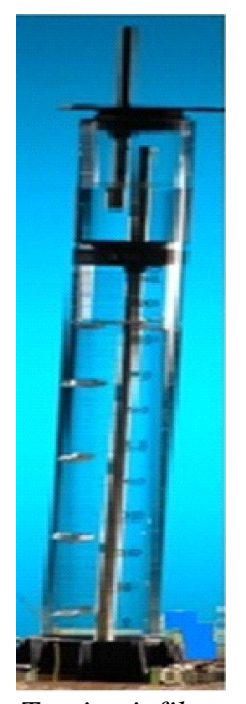

Fig. 1. Tension infiltrometer

bubbles first appeared was recorded. With the aid of a timer, readings were taken at intervals. The readings continued until a steady state of equilibrium (usually 180 minutes) was reached. The rate at which the water fell after every 30 seconds over a period of 10 minutes was recorded as well as the water level in the tension infiltrometer. If bubbles do not appear before 30 second, it means there is no flow of water to the ground then the flow after 30 second will be zero. The measurements were taken in 5 different points for each day of measurement in each treatment.

\section{RESULTS AND DISCUSSION}

Rainfall: Year 2009 commences very less rainfall in last 10 years and only $100 \mathrm{~cm}$ average rainfall was recorded. Maximum rainfall was recorded in the month of July $(268.20 \mathrm{~mm})$ and a dry spell was recorded in the month of December.

Soil texture and moisture: The soil texture of both the plots was dominated by sand followed by silt and clay. The soil comprised $79 \%$ sand, $15.4 \%$ silt and $5.6 \%$ clay at a depth of $0-10 \mathrm{~cm}$. Soil have $80.7 \%$ sand, $14.0 \%$ silt and $5.3 \%$ clay at a depth $10-15 \mathrm{~cm}$ and $80.2 .1 \%$ sand, $14.0 \%$ silt and $5.8 \%$ clay at a depth of $15-20 \mathrm{~cm}$ in the grazed plot. On the ungrazed plot at a depth of $0-10 \mathrm{~cm}$ soil comprised $77 \%$ sand, $18.0 \%$ silt and $9.6 \%$ clay, at $10-15$ $\mathrm{cm}$ depth the percent contribution of sand, silt and clay was $79.2 \%, 15.7 \%$ and $5.1 \%$ respectively. The percent amount of sand, silt and clay at the depth of $15-20 \mathrm{~cm}$ Table 1. Soil moisture percentage water holding capacity (\%) and soil texture at different depths on both the study sites

\begin{tabular}{|c|c|c|c|c|c|c|c|c|c|c|}
\hline \multirow[t]{2}{*}{ Plot } & \multirow[t]{2}{*}{ Soil Depth } & \multicolumn{3}{|c|}{ M oisture \% } & \multicolumn{3}{|c|}{ W ater holding capacity } & \multicolumn{3}{|c|}{ Soil T exture } \\
\hline & & Rainy & Winter & Summer & Rainy & Winter & Summer & Sand & Silt & Clay \\
\hline \multirow{4}{*}{ Grazed } & $0-10$ & 40.7 & 29.1 & 13.8 & 58.62 & 48.05 & 35.05 & 79.0 & 15.4 & 5.6 \\
\hline & $10-15$ & 33.6 & 20.3 & 12.1 & 50.05 & 40.76 & 33.08 & 80.7 & 14.0 & 5.3 \\
\hline & $15-20$ & 30.2 & 18.3 & 10.6 & 45.62 & 36.02 & 26.10 & 80.2 & 14.0 & 5.8 \\
\hline & $0-10$ & 44.2 & 30.3 & 16.3 & 62.85 & 49.80 & 38.38 & 77.0 & 18.0 & 5.0 \\
\hline \multirow[t]{2}{*}{ Ungrazed } & $10-15$ & 36.7 & 23.4 & 14.8 & 57.62 & 41.70 & 32.68 & 79.2 & 15.7 & 5.1 \\
\hline & $15-20$ & 33.3 & 20.6 & 14.0 & 51.02 & 35.65 & 27.75 & 81.1 & 13.7 & 5.2 \\
\hline
\end{tabular}


was $81.1 \%, 13.7 \%$ and $5.2 \%$ respectively. Sand percentage increases along with the depth at both the sites (Table 1). Results of the first volumetric soil water content test carried out on the 13th of January 2009, indicated that there was less moisture in the soil. After a month the soil moisture probe detected some moisture variation in the two sites and among the investigated plots between the sites. For the ungrazed plot the moisture percentage was maximum during the rainy season $(44.2 \%)$ and minimum during summers $(16.3 \%)$ at a depth of $0-10 \mathrm{~cm}$. While at a depth of 10-15 cm moisture percentage was recorded maximumduring rainy period (36.7\%) and minimum during summer $(14.8 \%)$ and at $15-20 \mathrm{~cm}$ depth the maximum and minimum values were observed $33.3 \%$ and $14 \%$ respectively for the rainy and summer season. For grazed site at a depth of $0-10 \mathrm{~cm}$ the maximum and minimum moisture content was recorded during rainy $(40.7 \%)$ and summer $(13.8 \%)$ season. At a depth of $10-15 \mathrm{~cm}$ the highest and lowest values were $33.6 \%$ and $12.1 \%$ respectively for ungrazed and grazed plots. At $15-20 \mathrm{~cm}$ of depth the values varied from $30.2 \%$ to $10.6 \%$ for the same seasons for both the study sites (Table 1).

A boveground net primary production (ANP): ANP

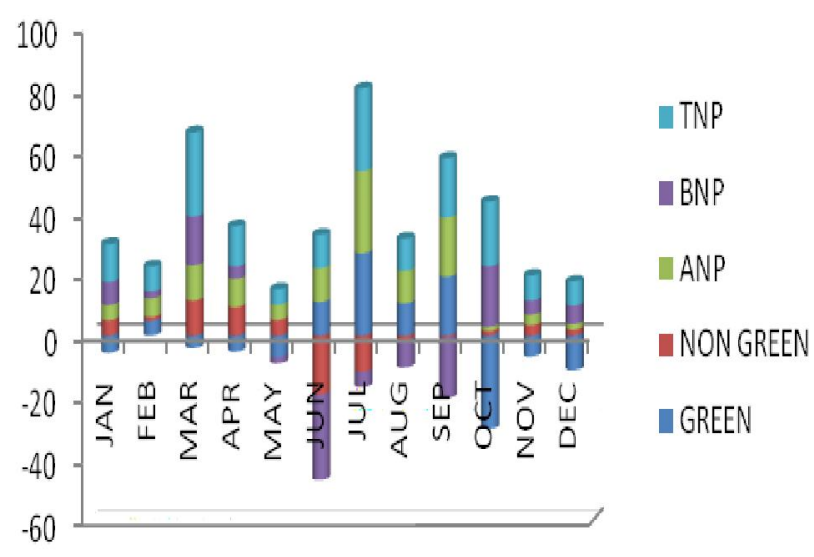

Fig. 2. Monthly variations in net primary productivity $\left(\mathrm{g} \mathrm{m}^{-2}\right)$ at ungrazed site.

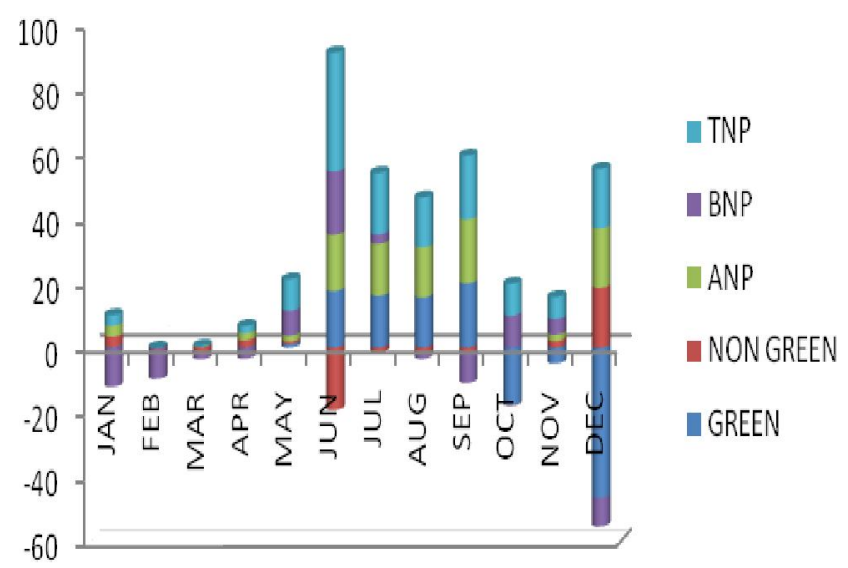

Fig. 3. Monthly variations in net primary productivity $\left(\mathrm{g} \mathrm{m}^{-2}\right)$ at grazed site. values for both the plots have been shown in Figs. 2 and 3 for ungrazed and grazed sites respectively. For the ungrazed plot productivity was computed maximum in the month of July $\left(26.75 \mathrm{~g} / \mathrm{m}^{2}\right)$ followed by September $\left(19.19 \mathrm{~g} / \mathrm{m}^{2}\right)$ and March $\left(11.43 \mathrm{~g} / \mathrm{m}^{2}\right)$, and minimum in the month of October $\left(1.45 \mathrm{~g} / \mathrm{m}^{2}\right)$. For the grazed plot, the aboveground net primary productivity was highest in September $\left(19.85 \mathrm{~g} / \mathrm{m}^{2}\right)$ and minimum production was recorded during February and October when the production was zero (Figs. 2 and 3 ).

Infiltration rate: Infiltration rates were substantially greater in summer than in winter. On day 1 the steady infiltration rate in summer was twice the winter rate. The infiltration rate in summer on day 2 , which is a better measure of the steady rate, was 2.5 times the winter rate. The differences between seasons were statistically very significant $(\mathrm{p}<0.001)$. Average infiltration rate in ungrazed site was $20.8 \mathrm{~cm} / \mathrm{hr}$; and for the grazed site it was $12.6 \mathrm{~cm} /$ hr. The stability of infiltration rates between years indicates an overall long-term stability of soil structure. Seasonal changes in soil structure, especially in the subsoil, are unlikely to be significant. As can be seen, there is almost a $1.5 \mathrm{inch} /$ hour infiltration rate difference

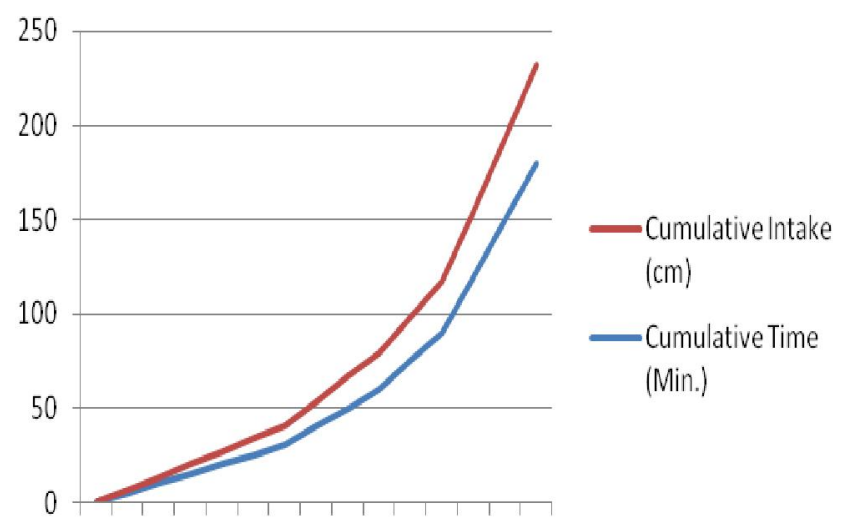

123456789101112131415

Fig. 4. Infiltration rates for the grazed site during the study year 2009.

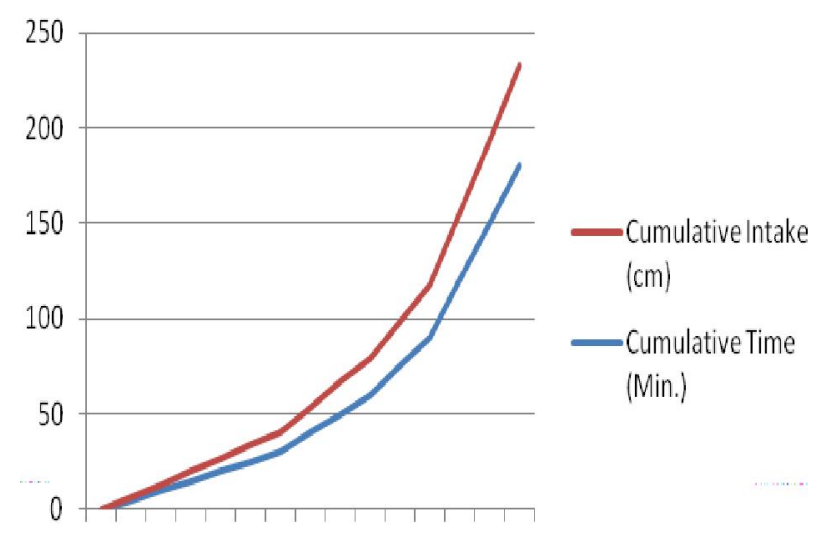

123456789101112131415

Fig. 5. Infiltration rates for the ungrazed site during the study year 2009 . 
between these two study sites. The infiltration capacity of the ungrazed site is stabilizing around 6.8 inches / hour, whereas the infiltration rate of the grazed pasture is stabilizing at 3.7 inches /hour (Figs. 4 and 5). Thus, for a storm event with a rainfall intensity of 2 inches /hour or less, the extremely grazed pasture will produce runoff for any storm falling at intensity greater than 0.5 inches / hour. From these preliminary results it is clear that soils under differing grazing management schemes differ in their ability to conserve water.

Fencing off rangeland to exclude livestock results in increase in the infiltration rate, as well as improvement soil moisture levels and biomass production, compared to the grazed site. This could be due to two effects: (i) Exclusion of livestock eliminates grazing, thus increasing biomass, and decreases trampling, thus improving infiltration rates (ii) Improved infiltration rates increase soil moisture content thus allowing for higher grass growth. If rainwater has not taken the form of runoff, or has not evaporated, then it has infiltrated into the ground. This is the pathway we desire to achieve. The actual infiltration capacity of a soil surface changes with percent soil moisture. That is, when a soil is initially dry, the rate at which it will absorb water is much greater. As the soil becomes saturated, its infiltration capacity drops, and eventually stabilizes. The two most important factors influencing the rate of infiltration are soil and vegetation. In order to infiltrate, water needs pathways. The soil properties which determine the size, shape, and conductivity of these pathways, are texture (sand, silt, clay), and aggregation. Vegetation also slows down water that is running off, allowing more time for it to infiltrate. In general, vegetative cover has more influence on infiltration rates than do the soil type and texture (Schwab et al., 1993). Rainfall is a major limiting factor for biomass production in temperate rangelands. This means simply that given all the factors that affect the health and growth of grasslands (e.g. nutrients, temperature, light energy, etc), the factor which tends to short circuit growth first is available water. This has led to an interest in managing grasslands for water conservation, which in turn means managing for optimum production. Other benefits of thinking in terms of water conservation are reduced erosion, reduced nutrient losses, and improved water quality. The increase in soil water occurs after ten days of the rainfall event. Following the dry spell in the late November / early December, soil water volume was decreasing at both the plots, approximately ten days after the dry spell. The decrease in soil water volume was observed lower for the grazed plot than for the ungrazed plot (Table 1).

The treatments examined show clear trends in soil moisture, infiltration rates and biomass production. Higher moisture levels were consistently recorded in ungrazed site than in grazed site, which can be explained by the higher amount of vegetation. It is observed that the largest increase in soil water volume occurs shortly after the largest rainfall event of the season which occurs in the month of July. The higher biomass production is encouraged by the higher soil moisture levels. The trends have been shown to be similar in the two soil types and under slightly different rainfall conditions.

The two essential parameters used in characterizing infiltration of water into soil profile are the rate and the cumulative amount. Measurement and numerical solutions have shown that the infiltration rate in a uniform, initially dry soil when rainfall does not limit infiltration, decrease with time and approaches an asymptotic minimum rate (Saiko and Zonn, 2003). Figs. 4 and 5 show the equilibrium infiltration rate of soils after a period of three hours (180mins) of field measurements. It is evident that, of the two study sites; ungrazed site recorded the highest infiltration value of $17.4 \mathrm{~cm} / \mathrm{hr}$. The high infiltration rate under this land use is due to the addition of organic matter and biological activities on the one hand and the loosening of surface soil arising from lateral spread of roots on the other. Sharma (2000) observed that the presence of a dense vegetal cover on the surface increases infiltration as soils under such land uses, have higher water absorption capacity in the event of heavy storm than other land uses.

The observed statistical relationships amongst soil, biomass and infiltration in this study support the interpretation that biomass constitutes a primary influence on infiltration capacity in water limited ecosystems. The data contradict a plausible hypothesis that improved soil texture increases infiltration capacity which leads to higher aboveground biomass. Note that the potential links between belowground biomass and infiltration capacity, however, cannot be assessed with the available data, and remain as an area where additional future work is required. In water limited climates power law relationships were relatively successful in describing the biomass-infiltration relationship.

Thus, it was concluded that the infiltration-biomass relationship does not generally persist in wetter climates. The processes contributing to the biomass-infiltration feedback are presumed to either saturate under humid conditions or the driver for plants to develop features that enhance infiltration rates is too weak to allow for the feedback to be observed. Complete exclusion of livestock, as represented by the fenced treatment, is not a realistic rangeland management option in areas where livestock are a major livelihood strategy. However, partial exclusion could be achieved by rotating grazing lands during the rainy season which is the time when the rangeland would be recovering and biomass production taking place. Further study would be required to determine the effect of this 
strategy on livestock biomass and the corresponding economic benefit, as well as additional probable benefits, such as reduction in soil siltation.

\section{REFERENCES}

Bergkamp,G. (1998). A hierarchial view of the interactions of runoff and infiltration with the vegetation and microtopography in semiarid shrublands. C atena, 33:201-299.

Bromley, J., Brower, J., Barker, A.P., Gaze, S.R. and Valentin, C. (1997). The role of surface water redistribution in an area of patterned vegetation in a semiarid environment, SouthWest Niger, J ournal of Hydrology, 198: 1-29.

Couteron, P. and Kokou, K.(1997). Woody vegetation spatial patterns in a semi-arid savanna of burkina faso, West Africa. Plant E cology, 132: 211-227.

Dunkerley, D.L. (2000a). Hydrologic effect of dryland shrubs, defining the spatial extent of modified soil water uptake rates at an Australian desert site.J ournal of Arid Environments, 45: 159-172.

Dunkerley, D.L. (2000b). Assessing the influence of shrubs and their interspaces on enhancing infiltration in an arid Australian shrubland. The Rangeland J . 22: 58-71.

Dunkerley, D.L. (2002). Infiltration rates and soil moisture in a groved Mulga community near Alice Spring, arid central Australia: Evidence for complex internal rainwater redistribution in a runoff-runon landscape. J ournal of Arid Environments, 51:199-219.

Lovell, C.J., Mharapara, I., Batchelor, C.H. and Brown, M.W. (1994).Small scale irrigation in Zimbabwe using shallow groundwater: an example of the need for integrated catchment management. Proceedings of the 25th Congress of the International Association of Hydrologists, Adelaide, Australia, 1: 581-585.

Metelerkamp, Bruce (2001). Sowacs soil water content sensors and measurement. Retrieved from www.sowacs.com.

Milton, S.J., Dean, W.R.J. and Richardson, D.M. (2003). Economic incentives for restoring natural capital in southern African rangelands. Frontiers in Ecology and Environment, 1:247-254.

Odum, E.P. (1960). Organic production and turnover in oldfield succession. E cology, 41: 34-49.

Platts, W. S. and Nelson, R. L. (1989). Characteristics of riparian plant communities with respect to livestock grazing Pp. 73-81 In Gresswell, R. E. (Ed.), Practical approaches to riparian resource management, May 8-11, 1989, Billings, MT. USDI, Bureau of Land Management.

Rietkerk M, Boerlijst MC, van Langevelde F, HilleRisLambers R, van de Koppel J, Kumar L, Prins H.H.T. (2002). Selforganization of vegetation in arid ecosystems. The American Naturalist, 160: 524-530.

Saco, P.M., G.R. Willgoose and Hancock,G.R. (2007). Ecogeomorphology and vegetation patterns in arid and semiarids regions. Hydrology and Earth System Sciences, 11: 1717-1730

Saiko, T. A. and Zonn, I. S. (2003). Landuse and management impact on structure and infiltration characteristics of soils in the North Region of Ohio. Soil Science, 1681:167-177.

Schwab, G.O., D.D. Fangmeier, W.J. Elliot and R.K. Frevert. (1993). Soil and Water Conservation Engineering. John Wiley \& Sons, Inc., New York, NY.

Scoones, I. (1992). Land degradation and livestock production in Zimbabwe's communal areas. Land Degradation and Rehabilitation, 3: 99-113.

Sharma, R. K. (2000). Hydrology and Water Resource Engineering, New Delhi. Manpat Rai Publication.

Singh, J.S. and Yadava, P.S. (1974). Seasonal variation in composition, plant biomass and net primary productivity of a tropical grassland at Kurukshetra, India. Ecological Monographs, 44:351-376.

Stomph, T.J., De Ridder, N., Steenhuis, T.S. and van den Giesen, N.C. (2002). Scale effects of hortonian overland flow and rainfall-runoff dynamics: laboratory validation of a processbased model. Earth Surface Processes and Landforms, 27 847-855.

Suresh, D. (2008). Land and Water Management Principles: New Delhi, Shansi Publishers.

Tami, D. and Leong, E. (2004). Effects of Hysterisis on steady state Infiltration in unsaturated slopes. Journal of Research, 16:195-202. NAA, Weather Report (2006). Nigerian Airport Authority monthly weather Chart for Calabar.

Weinwright, J.A., Parsons, A.J., Schlesinger, W.H., Abrahams, A.D. (2002). Hydrology-vegetation interactions in areas of discontinuous flow on a semiarid bajada, southern New Mexico. J ournal of Arid Envir onments, 51: 219-258. 